\title{
UNDERSTANDING THE CONCEPT OF INTELLIGENT OPERATIONS THROUGH ELPSA LEARNING WHEN LEARNING FROM HOME
}

\section{Ramuni A}

SMP Negeri 5 Sanggau Kalimantan Barat

E-mail: ramunialbina@gmail.com

\begin{tabular}{|c|c|}
\hline ARTICLE INFO & ABSTRACT \\
\hline $\begin{array}{l}\text { Received: } \\
\text { July, 24th } 2021 \\
\text { Revised: } \\
\text { August, } 15^{\text {th }} 2021 \\
\text { Approved: } \\
\text { August, } 17^{\text {th }} 2021\end{array}$ & $\begin{array}{l}\text { This Scientific Review in the form of best practice Learning the } \\
\text { ELPSA (Experience, Language, Picture, Symbol, Application) } \\
\text { model examines learning as an active process where students } \\
\text { construct their own way of understanding things through } \\
\text { individual thought processes and social interactions with } \\
\text { others in BDR activities. In this BDR activity, LKPD is used. This } \\
\text { Scientific Review (Best Practice) activity aims to improve } \\
\text { understanding of the concept of integer operations through } \\
\text { ELPSA learning for class VIIA students of SMPN } 5 \text { Sanggau. } \\
\text { This activity is carried out in the 2021/2022 school year, to be } \\
\text { precise in July. The success criteria set by the researchers are } \\
\text { student activities during the BDR learning process in the good } \\
\text { category, at least 80\% of the number of students can reach } \\
\text { the KKM which is 70. The results of this scientific review show } \\
\text { that students' understanding of learning integer operations } \\
\text { through ELPSA learning when BDR has been achieved by the } \\
\text { success criteria shown in the post test results. In more detail, } \\
\text { the percentage of achievement of the success criteria is as } \\
\text { follows: 1) student activities during the learning process are } \\
\text { in the good category, 2) There is an increase in the } \\
\text { percentage of students who have reached the KKM by } 31.25 \% \\
\text { from pre-test 56.25\% to 87.5\% in post test. From the results } \\
\text { of the study, it can be concluded that ELPSA learning is } \\
\text { effective in increasing the understanding of the concept of }\end{array}$ \\
\hline
\end{tabular}

\begin{tabular}{ll}
\hline & Ramuni A. (2021 Understanding the Concept of Intelligent Operations \\
& through ELPSA Learning when Learning from Home. Journal Eduvest. 1(8): \\
& $744-751$ \\
How to cite: & $2775-3727$ \\
E-ISSN: & https://greenpublisher.co.id/ \\
Published by: &
\end{tabular}




\begin{tabular}{ll}
\hline \multicolumn{5}{c}{ integer operations during BDR. } \\
\hline KEYWORDS & $\begin{array}{l}\text { Understanding of Mathematical Concepts, Integer Operations, } \\
\text { Learning ELPSA }\end{array}$ \\
\hline cC) (i) () & $\begin{array}{l}\text { This work is licensed under a Creative Commons } \\
\text { Attribution-ShareAlike 4.0 International License }\end{array}$ \\
\hline
\end{tabular}
INTRODUCTION

Learning mathematics with an understanding is essential (Van de Walle et al., 2016). To build and gain understanding of a new concept requires active and constructive effort through linking one concept to another of the students' own concepts (Subanji \& Supratman, 2015), and through the experience and knowledge that students have previously acquired (Stillman, 2000).

Based on the study of Constructivism Theory that teaching is not a matter of transferring information to students, it is not passively absorbing information from books or teachers (Prianto, Subanji, \& Sulandra, 2016). Therefore, in learning mathematics, students' activeness in building their own knowledge is a principle of learning mathematics (Carrillo-Yañez et al., 2018). Student activity in constructing problems is a requirement so that the concepts learned can be understood and acquire new knowledge thoroughly, deeply and not easily forgotten (Hansen, 2012).

Mathematics as one of the basic sciences plays an important role in various disciplines. In addition, learning mathematics can put pressure on the arrangement of reasoning, the formation of students' attitudes and skills in their application in everyday life as well as in studying various sciences.

In mathematics learning, generally the teacher is the main subject who gives the material, while students are objects who receive knowledge, students are "empty boxes" and the learning process is not conducive (Fauzan \& Sari, 2017). In the principle of learning mathematics, the teacher's task is to motivate students to think, ask questions, solve problems, discuss ideas and problem solving strategies from students and not "give" knowledge to students, but "facilitate" students. to be able to learn independently (Hidayati, Subanji, \& Sisworo, 2020). The learning process is carried out in a routine (routine), procedural (procedural), and the material is presented in the final formulation and discussion (final formula) causing low student activity.

Conceptual understanding is very important in learning mathematics (Mulyono \& Hapizah, 2018). With understanding, students can express their own ideas, ideas and conjectures. Students can also use informal strategies to solve problems, and can evaluate each other's thinking results. With understanding, students can develop reasoning skills, using evidence and logic (Pratiwi, Nusantara, Susiswo, Muksar, \& Subanji, 2019).

In essence, learning mathematics is an active process of constructing knowledge from students themselves (Rangkuti, 2014). To build and gain understanding of new concepts, active and constructive efforts are needed through linking one concept to another from the students themselves (Maharani \& Subanji, 2018). Active and constructive effort is a thought process and mental activity that involves knowledge and experience (Suatini, 2019) that students already have which can be done in various ways, for example by guessing, trying, investigating, communicating mathematical ideas both verbally and in writing in solving various problems faced (Supardi, 2015).

Integers are class VII material in the first semester. The whole number material has been studied by students since elementary school. Based on the 2013 Curriculum and the curriculum during the pandemic of integers, the seventh grade junior high school students learned to compare integers, operations to add and subtract integers, multiplication and 
division operations of integers, compare fractions, addition and subtraction of fractions, multiplication and division of fractions, recognize positive integers, least common multiples and common factors. The integer material discussed in this study is the operation of adding, subtracting, multiplying, and dividing integers.

Integers are very important material to be mastered by students in order to learn the following materials. However, there are still many students who find it difficult to determine integer operations. Students experience errors in determining the value of adding or subtracting positive and negative numbers. Students are still confused about the concept of adding, subtracting by multiplying (Kurniawan, 2019). The difficulties experienced by students when adding or subtracting positive and negative numbers, negative numbers and negative numbers. This shows that students do not understand the concept of integer operations. From the results of the pretest of 32 students from 5 questions given, it was found that 14 students had difficulty determining the operation of adding negative numbers with negative numbers and positive numbers with negative numbers.

To overcome the weak understanding of the concept of integer operations which results in student errors in calculating integer operations, the author tries to use the Experience, Language, Picture, Symbol, Application (ELPSA) design with the help of LKPD which is modified by the teacher himself. This study aims to describe the application of ELPSA learning in improve the understanding of integer operations in class VIIA students of SMPN 5 Sanggau in the 2021/2022 academic year". The indicators of success in this study are (1) The action is said to be successful if the student activities during the learning process are in the good category, (2) The student learning outcomes in this scientific review activity are said to be successful if the final score of $80 \%$ of students in the class has reached the KKM, which is at least at complete category $70 \mathrm{Y} 100$, where $\mathrm{Y}$ is the student's final grade.

\section{RESEARCH METHODS}

This scientific review activity was carried out at SMPN 5 Sanggau, on the basic competence of calculating integer operations. The subjects in this study were students of class VII-A, totaling 32 people. This scientific review activity was carried out in July 2021. At the planning stage, researchers developed learning tools which included, (1) lesson plans, (2). LKPD, (3). Student activity observation sheets, (4) Field Notes, (5) assessment of test learning outcomes. In the implementation of ELPSA learning activities, it is applied in a combination offline and online. The ELPSA learning was carried out at the BDR 1 activity on July 19, 2021. The results of observations of student learning activities were analyzed using the formula below.

$\left(\mathrm{X} \_\mathrm{i}\right)=\mathrm{A} \_\mathrm{i} / \mathrm{B} \times 100 \%$

Information $\left(X \_i\right)=$ the average score of the $i$-th observer, $i=1,2$

A】_ $i=$ total score of the $i$-th observer $i=1,2$

$\mathrm{B}=$ maximum total score

The average score obtained from each observer is then averaged again to get the final average score for student activities.

$\mathrm{X}=\left(\left(\mathrm{X} \_\right.\right.$1 $\left.)+\left(\mathrm{X} \_2\right)\right) / 2$

Description: $X=$ score of observations

$\mathrm{X} \rrbracket \_1=$ mean score of the first observer

$\mathrm{X} \rrbracket \_2=$ mean score of the second observer 
Ramuni A

Understanding the Concept of Intelligent Operations through ELPSA Learning when Learning from Home 


\section{Ramuni A}

Table 1 Percentage of Student Activity Categories Based on Observations

\begin{tabular}{ll} 
Percentage & Category \\
\hline $90 \%<\bar{X} \leq 100 \%$ & Very Good \\
\hline $75 \% \leq \bar{X} \leq 90 \%$ & Good \\
\hline $60 \%<\bar{X}<75 \%$ & Enough \\
\hline $0 \% \leq \bar{X} \leq 60 \%$ & Not good \\
\hline
\end{tabular}

(Source: Hobri, 2010)

The learning outcomes data in this study are included in the cognitive domain. After the posttest, the number of students who have reached the KKM is calculated. The KKM of mathematics at SMPN 5 Sanggau is 70. The results of the study of answers from the pre-test on the BDR 1 assignment are used to observe the level of students' understanding of the concepts of addition and subtraction of integers. Students are said to understand if $80 \%$ of students reach the KKM that has been determined in mathematics, which is 70 .

\section{RESULTS AND DISCUSSION}

\section{A. Pre Test Result}

Student learning outcomes in this study are the results of the pre-test which is done individually. The pre-test questions in BDR 1 consist of five questions. The list of pre test scores is in table 2 below:

Tabel 2 Score List Pre Test

\begin{tabular}{|c|c|c|c|c|c|c|c|c|c|c|}
\hline \multirow{2}{*}{ No } & \multirow{2}{*}{$\begin{array}{l}\text { Student's } \\
\text { Name }\end{array}$} & \multirow{2}{*}{ Gender } & \multicolumn{5}{|c|}{ Score } & \multirow{2}{*}{$\begin{array}{l}\text { Total } \\
\text { Score }\end{array}$} & \multirow{2}{*}{$\begin{array}{l}\text { Final } \\
\text { Score }\end{array}$} & \multirow{2}{*}{$\begin{array}{l}\text { Ability } \\
\text { Category }\end{array}$} \\
\hline & & & 1 & 2 & 3 & 4 & 5 & & & \\
\hline 1 & AS & $\mathrm{L}$ & 5 & 9 & 9 & 6 & 3 & 32 & 64 & Low \\
\hline 2 & AM & $\mathrm{L}$ & 6 & 0 & 9 & 5 & 4 & 24 & 48 & Low \\
\hline 3 & $\mathrm{~A}$ & $\mathrm{~L}$ & 6 & 12 & 9 & 10 & 7 & 44 & 88 & High \\
\hline 4 & $\mathrm{AH}$ & $\mathrm{P}$ & 5 & 0 & 9 & 10 & 4 & 28 & 56 & Low \\
\hline 5 & $\mathrm{~A}$ & $\mathrm{~L}$ & 6 & 5 & 3 & 9 & 4 & 27 & 54 & Low \\
\hline 6 & BRF & $\mathrm{L}$ & 3 & 6 & 12 & 9 & 10 & 40 & 80 & Enough \\
\hline 7 & $\mathrm{CV}$ & $\mathrm{P}$ & 4 & 12 & 9 & 10 & 7 & 42 & 84 & Enough \\
\hline 8 & $\mathrm{CA}$ & $\mathrm{P}$ & 1 & 6 & 12 & 6 & 7 & 32 & 64 & Low \\
\hline 9 & $\overline{\mathrm{DH}}$ & $\mathrm{L}$ & 6 & 12 & 9 & 9 & 11 & 47 & 94 & High \\
\hline 10 & $\mathrm{E}$ & $\mathrm{P}$ & 1 & 6 & 4 & 9 & 2 & 22 & 44 & Low \\
\hline 11 & FLH & $\mathrm{L}$ & 6 & 12 & 9 & 10 & 7 & 44 & 88 & High \\
\hline 12 & FDH & $\mathrm{L}$ & 6 & 12 & 9 & 10 & 7 & 44 & 88 & High \\
\hline 13 & HS & $\mathrm{L}$ & 1 & 1 & 4 & 4 & 8 & 18 & 36 & Low \\
\hline 14 & IRM & $\mathrm{L}$ & 6 & 8 & 9 & 10 & 7 & 40 & 80 & Enough \\
\hline 15 & $\mathrm{JCL}$ & $\mathrm{P}$ & 6 & 12 & 9 & 10 & 8 & 45 & 90 & High \\
\hline 16 & JR & $\mathrm{L}$ & 6 & 8 & 9 & 7 & 10 & 40 & 80 & Enough \\
\hline 17 & $\mathrm{KZ}$ & $\mathrm{P}$ & 6 & 12 & 9 & 10 & 13 & 50 & 100 & High \\
\hline 18 & MF & $\mathrm{P}$ & 1 & 6 & 10 & 9 & 6 & 32 & 64 & Low \\
\hline 19 & MIA & $\mathrm{L}$ & 6 & 8 & 5 & 0 & 1 & 20 & 40 & Low \\
\hline 20 & NS & $\mathrm{P}$ & 1 & 6 & 4 & 9 & 2 & 22 & 44 & Low \\
\hline 21 & $\mathrm{NZU}$ & $\mathrm{P}$ & 6 & 12 & 9 & 10 & 5 & 42 & 84 & Enough \\
\hline 22 & OVD & $\mathrm{L}$ & 6 & 1 & 9 & 10 & 5 & 31 & 62 & Low \\
\hline 23 & $\mathrm{R}$ & $\mathrm{L}$ & 6 & 12 & 9 & 10 & 8 & 45 & 90 & High \\
\hline
\end{tabular}




\section{Ramuni A}

\begin{tabular}{lllllllllll}
\hline 24 & RE & L & 4 & 12 & 9 & 10 & 5 & 40 & 80 & Enough \\
\hline 25 & RR & P & 6 & 12 & 9 & 10 & 7 & 44 & 88 & High \\
\hline 26 & RH & P & 1 & 1 & 6 & 4 & 10 & 20 & 40 & Low \\
\hline 27 & SS & L & 4 & 12 & 9 & 10 & 7 & 42 & 84 & Enough \\
\hline 28 & SSP & L & 4 & 12 & 9 & 10 & 5 & 40 & 80 & Enough \\
\hline 29 & STA & L & 1 & 6 & 8 & 4 & 6 & 25 & 50 & Low \\
\hline 30 & TRH & P & 1 & 1 & 6 & 4 & 10 & 20 & 40 & Low \\
\hline 31 & VE & P & 6 & 8 & 9 & 10 & 7 & 40 & 80 & Enough \\
\hline 32 & Y & P & 6 & 8 & 9 & 10 & 7 & 40 & 80 & Enough \\
\hline $\begin{array}{l}\text { Percentage of complete learning } \\
\text { outcomes }\end{array}$ & & & & & & & & & &
\end{tabular}

*) Information : $\mathrm{L}=$ Male, $\mathrm{P}=$ Female

\begin{tabular}{|l|l|}
\hline & Completed value \\
\hline & High ability category \\
\hline & Medium ability category \\
\hline & Low ability category \\
\hline
\end{tabular}

After carrying out the first cycle of actions, information was obtained that:

1) The results of the observation of student activities in the good category.

2) The completeness of the students' pre-test scores reached a percentage of $56.25 \%$.

Because criteria (1) and (2) have not been achieved, the actions in cycle I have not been successful. Thus the research was continued in cycle II. In cycle II the researchers made several improvements including the following:

a) The implementation of material review before the final test must be maximized.

b) The provision of LKPD must be more attractive according to clear sources

c) Giving the material is continued to the next material, namely multiplication and division

d) The effectiveness and strengthening of actions at each stage of the ELPSA carried out during the BDR learning process is more concerned.

e) Giving additional questions about integer operations to be given at the application stage.

\section{B. Post Test}

Student learning outcomes in this study were the results of the posttest at the end of BDR 1 which was done individually. The posttest consists of five questions. Table 2 below is a list of posttest scores.

Table 2 List of posttest scores

\begin{tabular}{|c|c|c|c|c|c|c|c|c|c|c|}
\hline \multirow{2}{*}{ No } & \multirow{2}{*}{$\begin{array}{l}\text { Student's } \\
\text { Name }\end{array}$} & \multirow{2}{*}{ Gender } & \multicolumn{5}{|c|}{ Score } & \multirow{2}{*}{$\begin{array}{l}\text { Total } \\
\text { Score }\end{array}$} & \multirow{2}{*}{$\begin{array}{l}\text { Final } \\
\text { Score }\end{array}$} & \multirow{2}{*}{$\begin{array}{l}\text { Ability } \\
\text { Category }\end{array}$} \\
\hline & & & 1 & 2 & 3 & 4 & 5 & & & \\
\hline 1 & AS & $\mathrm{L}$ & 9 & 6 & 4 & 7 & 7 & 33 & 66 & Low \\
\hline 2 & AM & L & 9 & 5 & 5 & 6 & 7 & 32 & 64 & Low \\
\hline 3 & A & $\mathrm{L}$ & 8 & 7 & 4 & 11 & 14 & 44 & 88 & High \\
\hline 4 & $\mathrm{AH}$ & $\mathrm{P}$ & 8 & 7 & 4 & 7 & 16 & 42 & 84 & Enough \\
\hline
\end{tabular}




\begin{tabular}{|c|c|c|c|c|c|c|c|c|c|c|}
\hline \multirow{2}{*}{ No } & \multirow{2}{*}{$\begin{array}{l}\text { Student's } \\
\text { Name }\end{array}$} & \multirow{2}{*}{ Gender } & \multicolumn{5}{|c|}{ Score } & \multirow{2}{*}{$\begin{array}{l}\text { Total } \\
\text { Score }\end{array}$} & \multirow{2}{*}{$\begin{array}{l}\text { Final } \\
\text { Score }\end{array}$} & \multirow{2}{*}{$\begin{array}{l}\text { Ability } \\
\text { Category }\end{array}$} \\
\hline & & & 1 & 2 & 3 & 4 & 5 & & & \\
\hline 5 & A & $\mathrm{L}$ & 8 & 7 & 8 & 6 & 16 & 45 & 90 & High \\
\hline 6 & BRF & $\mathrm{L}$ & 8 & 7 & 8 & 11 & 16 & 50 & 100 & High \\
\hline 7 & $\mathrm{CV}$ & $\mathrm{P}$ & 8 & 7 & 8 & 11 & 16 & 50 & 100 & High \\
\hline 8 & $\mathrm{CA}$ & $\mathrm{P}$ & 8 & 7 & 8 & 6 & 16 & 45 & 90 & High \\
\hline 9 & $\mathrm{DH}$ & $\mathrm{L}$ & 8 & 7 & 8 & 11 & 16 & 50 & 100 & High \\
\hline 10 & $E$ & $\mathrm{P}$ & 8 & 7 & 4 & 7 & 16 & 42 & 84 & Enough \\
\hline 11 & FLH & $\mathrm{L}$ & 9 & 6 & 4 & 7 & 7 & 33 & 66 & Low \\
\hline 12 & $\mathrm{FDH}$ & $\mathrm{L}$ & 8 & 7 & 8 & 11 & 14 & 48 & 96 & High \\
\hline 13 & HS & $\mathrm{L}$ & 7 & 8 & 8 & 11 & 16 & 50 & 100 & High \\
\hline 14 & IRM & $\mathrm{L}$ & 6 & 6 & 5 & 8 & 16 & 41 & 82 & Enough \\
\hline 15 & JCL & $P$ & 7 & 8 & 4 & 11 & 16 & 46 & 92 & High \\
\hline 16 & JR & $\mathrm{L}$ & 7 & 8 & 8 & 11 & 16 & 50 & 100 & High \\
\hline 17 & $\mathrm{KZ}$ & $\mathrm{P}$ & 7 & 8 & 4 & 11 & 16 & 46 & 92 & High \\
\hline 18 & $\mathrm{MF}$ & $\mathrm{P}$ & 7 & 3 & 8 & 11 & 16 & 45 & 90 & High \\
\hline 19 & MIA & $\mathrm{L}$ & 6 & 6 & 5 & 8 & 16 & 41 & 82 & Enough \\
\hline 20 & NS & $\mathrm{P}$ & 7 & 8 & 3 & 11 & 16 & 45 & 90 & High \\
\hline 21 & $\mathrm{NZU}$ & $\mathrm{P}$ & 7 & 8 & 8 & 11 & 16 & 50 & 100 & High \\
\hline 22 & OVD & $\mathrm{L}$ & 7 & 6 & 8 & 3 & 7 & 31 & 62 & Low \\
\hline 23 & $\mathrm{R}$ & $\mathrm{L}$ & 7 & 8 & 8 & 11 & 16 & 50 & 100 & High \\
\hline 24 & $\mathrm{RE}$ & $\mathrm{L}$ & 7 & 8 & 5 & 4 & 16 & 40 & 80 & Enough \\
\hline 25 & RR & $\mathrm{P}$ & 7 & 8 & 8 & 11 & 16 & 50 & 100 & High \\
\hline 26 & RH & $P$ & 7 & 8 & 8 & 11 & 16 & 50 & 100 & High \\
\hline 27 & SS & $\mathrm{L}$ & 7 & 8 & 8 & 11 & 16 & 50 & 100 & High \\
\hline 28 & SSP & $\mathrm{L}$ & 7 & 8 & 8 & 11 & 16 & 50 & 100 & High \\
\hline 29 & STA & $\mathrm{L}$ & 6 & 6 & 5 & 8 & 16 & 41 & 82 & Enough \\
\hline 30 & TRH & $\mathrm{P}$ & 7 & 8 & 5 & 4 & 16 & 40 & 80 & Enough \\
\hline 31 & VE & $\mathrm{P}$ & 7 & 8 & 8 & 11 & 16 & 50 & 100 & High \\
\hline 32 & $\mathrm{Y}$ & $\mathrm{P}$ & 7 & 8 & 8 & 11 & 16 & 50 & 100 & High \\
\hline \multicolumn{8}{|c|}{$\begin{array}{l}\text { Percentage of complete learning } \\
\text { outcomes }\end{array}$} & \multicolumn{3}{|l|}{$87,5 \%$} \\
\hline
\end{tabular}

*) Information : $\mathrm{L}=$ Male, $\mathrm{P}=$ Female

\begin{tabular}{|l|l|}
\hline & Completed value \\
\hline & High ability category \\
\hline & Medium ability category \\
\hline & Low ability category \\
\hline
\end{tabular}

Based on the results of the post-test, the final score of students' completeness reached a percentage of $87.5 \%$. While the percentage of student activity in the good category. Based on the results of the analysis, it is known that all aspects of the success criteria have been achieved. So it can be concluded that this research has reached the criteria of success. 


\section{CONCLUSION}

Based on the results of the study, it can be concluded that ELPSA learning can understand the concept of integer operations for class VIIA SMPN 5 Sanggau with details of the success that has been achieved in cycle II, namely: (1) the results of observing student activities in good categories (2) presenting students who have reached the KKM ie the final score of at least 70 is $87.5 \%$. On this discussion, the writer gives advice to mathematics teachers who teach at other schools who are also experiencing problems with student learning outcomes. Some things that need to be well prepared are group division and group arrangement when face-to-face offline activities are limited. In addition, making the application in the image also needs to be considered and prepared beforehand.

\section{REFERENCES}

Carrillo-Yañez, José, Climent, Nuria, Montes, Miguel, Contreras, Luis C., FloresMedrano, Eric, Escudero-Ávila, Dinazar, Vasco, Diana, Rojas, Nielka, Flores, Pablo, \& Aguilar-González, Álvaro. (2018). The mathematics teacher's specialised knowledge (MTSK) model. Research in Mathematics Education, 20(3), 236-253.

Fauzan, Ahmad, \& Sari, Oci Yulina. (2017). Pengembangan Alur Belajar Pecahan Berbasis Realistic Mathematics Education. Prosiding Seminar Nasional Pascasarjana Unsyiah.

Hansen, Edmund J. (2012). Idea-based learning: A course design process to promote conceptual understanding. Stylus Publishing, LLC.

Hidayati, Vivi Rachmatul, Subanji, Subanji, \& Sisworo, Sisworo. (2020). Students' Mathematical Connection Error in Solving PISA Circle Problem. JIPM (Jurnal Ilmiah Pendidikan Matematika), 8(2), 76-84.

Kurniawan, Indra. (2019). Analisis Kesulitan Siswa dalam Penyelesain Soal Aljabar Serta Alternatif Pemecahannya. Jurnal Theorems, 4(1), 301722.

Maharani, Indah Puspitasari, \& Subanji, Subanji. (2018). Scaffolding Based on Cognitive Conflict in Correcting the Students' Algebra Errors. International Electronic Journal of Mathematics Education, 13(2), 67-74.

Mulyono, Budi, \& Hapizah, Hapizah. (2018). Pemahaman konsep dalam pembelajaran matematika. Kalamatika: Jurnal Pendidikan Matematika, 3(2), 103-122.

Pratiwi, Enditiyas, Nusantara, Toto, Susiswo, Susiswo, Muksar, Makbul, \& Subanji, Subanji. (2019). Characteristics of students' cognitive conflict in solving a problem based on information processing theory. International Journal of Learning, Teaching and Educational Research, 18(2), 76-88.

Prianto, Agus, Subanji, Subanji, \& Sulandra, I.Made. (2016). Berpikir Kreatif Dalam Pembelajaran RME. Jurnal Pendidikan: Teori, Penelitian, Dan Pengembangan, 1(7), 1442-1448.

Rangkuti, Ahmad Nizar. (2014). Konstruktivisme dan Pembelajaran Matematika. Darul Ilmi: Jurnal Ilmu Kependidikan Dan Keislaman, 2(2).

Stillman, Gloria. (2000). Impact of prior knowledge of task context on approaches to applications tasks. The Journal of Mathematical Behavior, 19(3), 333-361.

Suatini, Ni Kadek Ayu. (2019). Langkah-langkah Mengembangkan Kemampuan Berpikir Kritis Pada Siswa. Kamaya: Jurnal Ilmu Agama, 2(1), 41-50.

Subanji, Rajiden, \& Supratman, Ahman Maedi. (2015). The pseudo-covariational reasoning thought processes in constructing graph function of reversible event 
dynamics based on assimilation and accommodation frameworks. Research in Mathematical Education, 19(1), 61-79.

Supardi, U. S. (2015). Peran berpikir kreatif dalam proses pembelajaran matematika. Formatif: Jurnal Ilmiah Pendidikan MIPA, 2(3).

Van de Walle, J., Karp, K., Lovin, L., Bay-Williams, J., Education, Pearson, Sowder, J., Sowder, L., \& Nickerson, S. (2016). Required Text. 